\title{
1 Using Machine Learning of Clinical Data to Diagnose 2 COVID-19
}

3 Wei Tse Li ${ }^{+1}$, Jiayan Ma' ${ }^{+, 1}$, Neil Shende ${ }^{+, 1}$, Grant Castaneda ${ }^{1}$, Jaideep Chakladar ${ }^{1}$, Joseph C. Tsai ${ }^{1}$,

4 Lauren Apostol ${ }^{1}$, Christine O. Honda ${ }^{1}$, Jingyue $\mathrm{Xu}^{1}$, Lindsay M. Wong', Tianyi Zhang ${ }^{1}$, Abby Lee',

5 Aditi Gnanasekar', Thomas K. Honda', Selena Z. Kuo ${ }^{2}$, Michael Andrew Yư ${ }^{3}$, Eric Y. Chang',

6 Mahadevan “Raj” Rajasekaran5, Weg M. Ongkeko*,1

7

8
${ }^{1}$ Department of Otolaryngology-Head and Neck Surgery, University of California San Diego, La Jolla, CA 92093; Research Service, VA San Diego Healthcare System San Diego, La Jolla, CA 92161, USA

${ }^{2}$ Department of Medicine, Columbia University Medical Center, New York, NY 10032, USA

${ }^{3}$ Department of Internal Medicine, Emory University School of Medicine, Atlanta, GA 30322, USA

${ }^{4}$ Department of Radiology, University of California San Diego, La Jolla, CA 92093, USA; Radiology Service, VA San Diego Healthcare System San Diego, La Jolla, CA 92161, USA

${ }^{5}$ Department of Urology, University of California San Diego, La Jolla, CA 92093, US; Urology Service, VA San Diego Healthcare System, San Diego, CA 92161, USA

* Correspondence: rongkeko@health.ucsd.edu

$\dagger$ Authors contributed equally

Received: date; Accepted: date; Published: date

Abstract: The recent pandemic of Coronavirus Disease 2019 (COVID-19) has placed severe stress on healthcare systems worldwide, which is amplified by the critical shortage of COVID-19 tests. In this study, we propose to generate a more accurate diagnosis model of COVID-19 based on patient symptoms and routine test results by applying machine learning to reanalyzing COVID-19 data from 151 published studies. We aimed to investigate correlations between clinical variables, cluster COVID-19 patients into subtypes, and generate a computational classification model for discriminating between COVID -19 patients and influenza patients based on clinical variables alone. We discovered several novel associations between clinical variables, including correlations 

gender, and reported symptoms. Finally, we trained an XGBoost model to achieve a sensitivity of 92.5\% and a specificity of $97.9 \%$ in discriminating COVID-19 patients from influenza patients. We demonstrated that computational methods trained on large clinical datasets could yield ever more accurate COVID-19 diagnostic models to mitigate the impact of lack of testing. We also presented previously unknown COVID-19 clinical variable correlations and clinical subgroups.

\section{Introduction}

COVID-19 is a severe respiratory illness caused by the virus SARS-Cov-2. The scientific community has focused on this disease with near unprecedented intensity. However, the majority of primary studies published on COVID-19 suffered from small sample sizes[1, 2]. While a few primary research studies reported on dozens or hundreds of cases, many more studies reported on less than 20 patients $[3,4]$. Therefore, there is an urgent need to collate all available published data on the clinical characteristics of COVID-19 from different studies to construct a comprehensive dataset for gaining insights into the pathogenesis and clinical characteristics of COVID-19. In this study, we aim to perform a large-scale meta-analysis to synthesize all published studies with COVID-19 patient clinical data, with the goal of uncovering novel correlations between clinical variables in COVID-19 patients. We will then apply machine learning to reanalyze the data and construct a computational model for predicting whether someone has COVID-19 based on their clinical information alone. 
of their most effective tools for containing a pandemic: identification of case hotspots and targeted action towards regions and specific individuals with the disease[5]. The scale of the testing shortage calls for methods for diagnosing COVID-19 that use resources local healthcare facilities currently have. We propose the development of a disease prediction model based on clinical variables and standard clinical laboratory tests.

A number of meta-analyses have been done on COVID-19, but almost none of them comprehensively included data from all published studies. Three different meta-analyses, published in February, March, and April of 2020, included data from 10, 8, and 31 articles, respectively[6-8]. We included 151 articles, comprising 413 patients, in our analysis. To the best of our knowledge, no study has performed a large-scale machine learning analysis on clinical variables to obtain a diagnostic model. We believe that our study will be an important step towards leveraging the full extent of published clinical information on COVID-19 patients to inform diagnosis of COVID-19, instead of relying on general guidelines for symptoms that do not take into account the association between different clinical variables.

\section{Results}

\subsection{Compilation of patient data and summary of clinical variables}

After compiling information from 151 published studies, we present a total of 42 different clinical variables, including 21 categorical and 21 continuous variables, that are reported in more than 1 study. Discrete variables include nominal categorical variables like gender, which is $49.49 \%$ (194 patients) male and 50.51\% (198 patients) female, and ordinal categorical variables like lymphocytes level, of which 86 patients (48.86\%) have low levels, 73 patients $(41.47 \%)$ have normal levels, and 17 patients $(9.65 \%)$ have high levels. Continuous variables include age, which has a mean of 38.91 years and variance 21.86 years, and serum neutrophil levels, which has a mean of $6.85 \times 10^{9}$ cells/L and a variance of $12.63 \times 10^{9}$ cells/L. Certain variables, including all counts of blood cell populations, have both ordinal and continuous components. The continuous component describes the raw count of these populations, while the ordinal component describes whether these counts are 
medRxiv preprint doi: https://doi.org/10.1101/2020.06.24.20138859; this version posted June 24, 2020. The copyright holder for this preprint

(which was not certified by peer review) is the author/funder, who has granted medRxiv a license to display the preprint in perpetuity.

All rights reserved. No reuse allowed without permission.

4 of 21

78

79

80

81

83

84

85

86

87

88

89

90

91

92

93

94
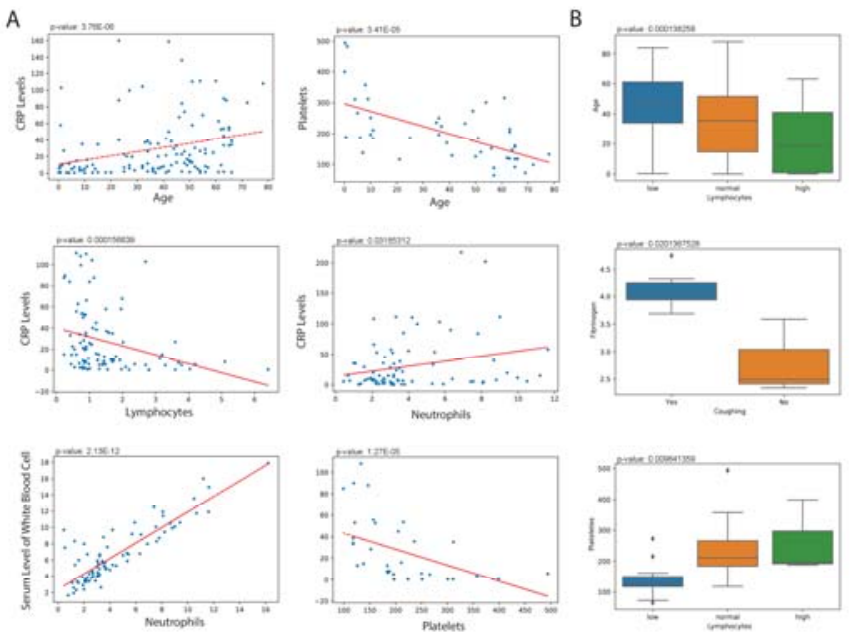
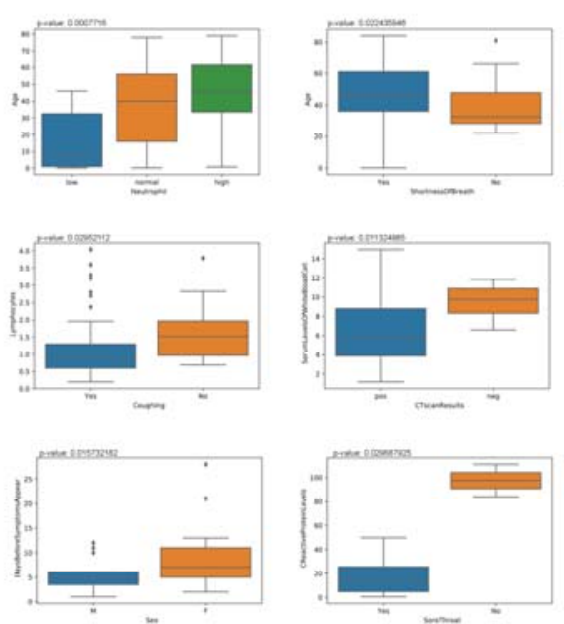

Figure 1. Select correlations with continuous clinical variables for COVID-19 patients. A. 
medRxiv preprint doi: https://doi.org/10.1101/2020.06.24.20138859; this version posted June 24, 2020. The copyright holder for this preprint

(which was not certified by peer review) is the author/funder, who has granted medRxiv a license to display the preprint in perpetuity.

All rights reserved. No reuse allowed without permission.

5 of 21

98

99

100

101

102

103

104

105

106

107

108

109

110

111

112

113

114

115

116
For pairs of one continuous and one discrete variable, the Kruskal-Wallis test is applied $(p<0.05)$. Among 319 Kruskal-Wallis comparisons, 36 correlations were significant. Some of the significant pairs overlapped with correlations between two continuous variables for variables that have both ordinal and continuous components. Such correlations are not displayed twice in Figure 1.

We found again that age correlated significantly with multiple variables, including negative correlation with lymphocyte levels, positive correlation with neutrophil levels, and positive correlation with shortness of breath (Figure 1B). Other interesting associations were also discovered. Coughing was found to be correlated with increasing fibrinogen levels and decreasing lymphocyte levels. Those with lower levels of serum white blood cells (leukocytes) are more likely to report a positive CT scan result for pneumonia. Females may experience a greater number of days before symptoms appear. Finally, we found that sore throat decreases with increasing CRP levels (Figure 1B).

For pairs of two categorical variables, a two-tail chi-square test is applied. 42 out of 309 comparisons showed significant correlation, with few overlaps with former tests. Gender is involved in 6 of the significant correlation, indicating significant gender differences in COVID-19. Contingency tables of selected significant correlations are shown in Figure 2. Males were found to have higher lymphocyte and neutrophil levels than females (Figure 2A,B). Females were found to be more likely to have lower levels of serum white blood cells (Figure 2C). 


\begin{tabular}{|c|c|c|c|c|}
\hline \multicolumn{4}{|c|}{ Contingency Table: Lymphocyte Levels vs Gender } & p-value: 0.02015 \\
\hline & & Male & Female & All \\
\hline & Low & 39 & 47 & 86 \\
\hline & Normal & 33 & 39 & 72 \\
\hline & High & 14 & 3 & 17 \\
\hline & All & 86 & 89 & 175 \\
\hline
\end{tabular}

B

Contingency Table: Neutrophil Levels vs Gender
\begin{tabular}{|l|l|l|l|}
\hline & Male & Female & All \\
\hline Low & 10 & 5 & 15 \\
\hline Normal & 35 & 48 & 83 \\
\hline High & 20 & 9 & 29 \\
\hline All & 65 & 62 & 127 \\
\hline
\end{tabular}

C

\begin{tabular}{|c|c|c|c|c|}
\hline \multirow{5}{*}{ 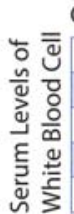 } & \multirow{5}{*}{ 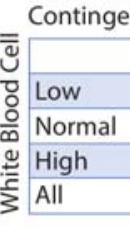 } & \multicolumn{3}{|r|}{ p-value: 0.002905} \\
\hline & & 16 & 39 & 55 \\
\hline & & 50 & 40 & 90 \\
\hline & & 12 & 7 & 19 \\
\hline & & 78 & 86 & 164 \\
\hline
\end{tabular}

117

\subsection{Clustering of patients into subcategories of COVID-19} be ignored from the SOM model when deriving a neural topology.

Figure 2. Correlations between gender and another categorical variable. A. Correlation between lymphocyte level categories and gender. B. Correlation between neutrophil level categories and gender. C. Correlation between serum leukocyte level categories and gender. A contingency table and a bar plot of the number of patients in each level are displayed for each correlation.

We next aim to cluster COVID-19 patients based on clinical variables using machine learning. We chose the well-known SOM algorithm for clustering. SOM is a neural network that has a set of neurons organized on a 2D grid[10]. All neurons are connected to all input units (individual patients) by a weight vector. The weights are determined through iterative evaluations of a Gaussian neighborhood function, with the result of creating a 2D topology of neurons to model the similarity of input units (individual patients). The algorithm outputs a map that assigns each sample to one of the neurons on the 2D grid, with samples in the same neuron being the most similar to one another. Similarity of samples decrease with distance between neurons on the 2D map. Missing variables will

We generated square SOM neuron grids with side lengths 3 through 20 using the trainSOM function in the R package SOMbrero. The grids with side lengths 3, 4, 5, 7, and 9 all had topographic 
medRxiv preprint doi: https://doi.org/10.1101/2020.06.24.20138859; this version posted June 24, 2020. The copyright holder for this preprint

(which was not certified by peer review) is the author/funder, who has granted medRxiv a license to display the preprint in perpetuity.

All rights reserved. No reuse allowed without permission.

7 of 21

135 errors of 0 (Figure $3 \mathrm{~A})$. Of these, we chose the biggest grid ( $9 \times 9=81$ clusters) as our model. After the

136 patients were assigned to neurons, an analysis of variance (ANOVA) test was performed to test

137 which variables actively participate in the clustering. Of the 48 clinical variables we inputted, 27

138 were found to have very high significativity $(p<0.001)$ (Table S2). We then reran the SOM using the

13927 variables on a $9 \times 9$ grid. This grid is displayed on Figure 3B and has a final energy of 8.139248 . The

140 largest neuron has 39 patients, the second largest has 37 , the third largest has 21 , and the fourth

141 largest has 20 (Figure 3C). 
medRxiv preprint doi: https://doi.org/10.1101/2020.06.24.20138859; this version posted June 24, 2020. The copyright holder for this preprint (which was not certified by peer review) is the author/funder, who has granted medRxiv a license to display the preprint in perpetuity. All rights reserved. No reuse allowed without permission.
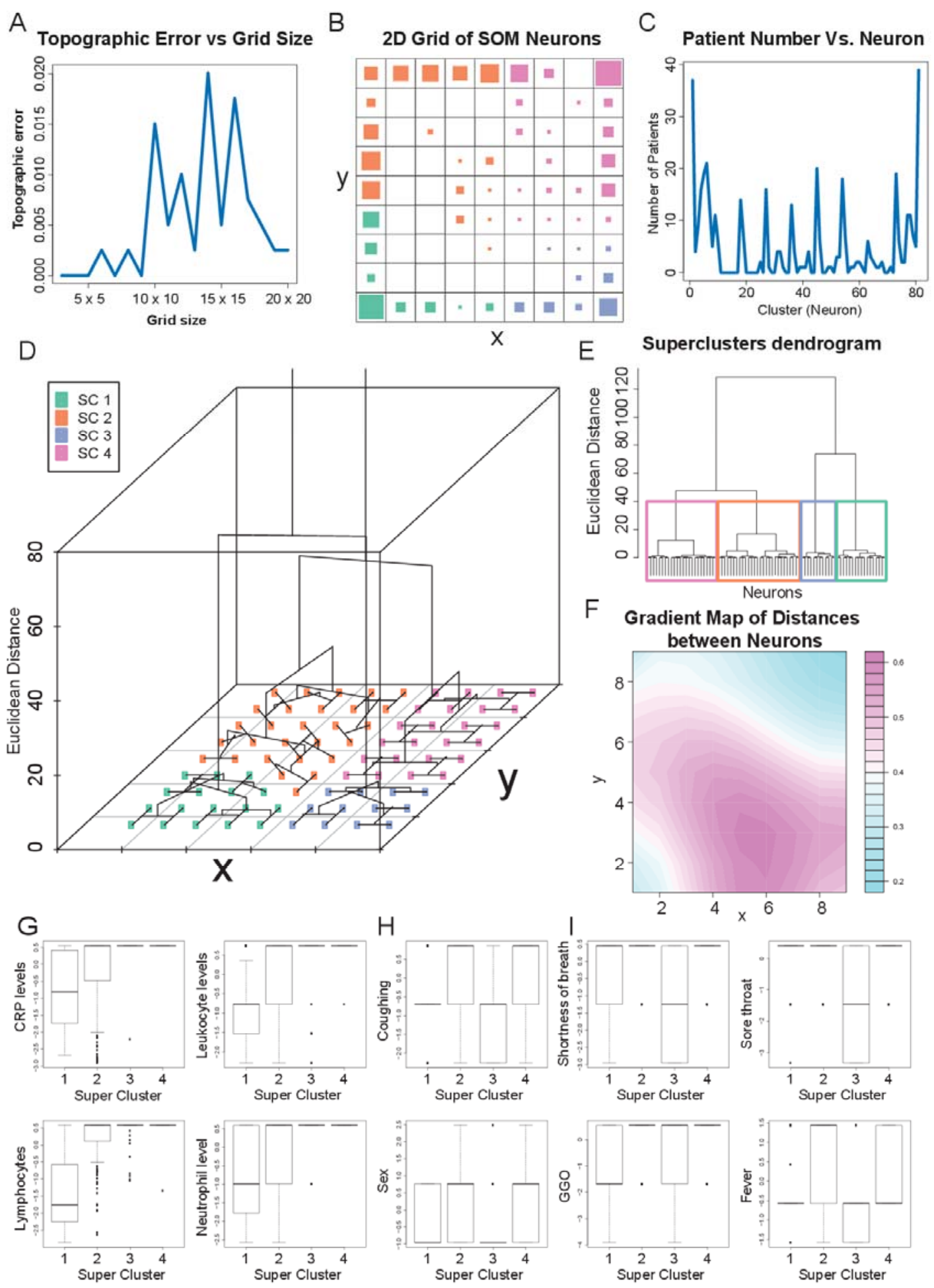

\section{2}


medRxiv preprint doi: https://doi.org/10.1101/2020.06.24.20138859; this version posted June 24, 2020. The copyright holder for this preprint

(which was not certified by peer review) is the author/funder, who has granted medRxiv a license to display the preprint in perpetuity.

All rights reserved. No reuse allowed without permission.

9 of 21

146

147

148

149

150

151

152

153

154

155

156

157

158

159

160

161

162

163

164

165

166

167

168

169

170

171

172

173

square in each grid represents the number of patients associated with each neuron. The color code corresponds to superclusters presented in panel D. C. Plot of number of patients in each neuron. D. 3D dendrogram summarizing the neurons into superclusters. E. 2D dendrogram with the same information as the dendrogram in part $\mathrm{D}$. In both dendrograms, the vertical axis represents the relative distance between clusters, which can be known between any two clusters by looking at the branch point where they diverge. F. Gradient map where light blue regions of the SOM depict higher similarity of neurons with each other. G. Boxplots of immune-associated clinical variables that differentiate superclusters. H. Boxplots in which superclusters 1 and 3 display similar trends. I. Boxplots in which only one supercluster has a median at a different value from the other three. All variables have been previously normalized. For binary variables, only three possible positions on the vertical axis is possible: the bottom one being no, the middle one being yes, and the top one being missing. For the gender (sex) variable, the bottom position is female, the middle is male, and the top one is missing.

\subsection{Clinical characteristics of COVID-19 clusters}

We then examined the defining features of patients assigned to the same neurons. We investigated four neurons associated with the largest number of patients and identified the four variables with the smallest nonzero standard deviations for each patient cluster. In the largest cluster, with 39 patients, the four smallest nonzero standard deviations were for the variables region of infection, sore throat, RT-PCR results, and coughing. In the second largest cluster, with 37 patients, the variables were baby death if pregnant, lymphocyte levels, fever, and coughing. In the next largest cluster, with 21 patients, the variables were sore throat, duration of illness in days, RT-PCR results, and coughing. In the fourth largest cluster, with 20 patients, the variables were sore throat, fever, coughing, and age.

We next used the function superClass to compute the relative Euclidean distances between the 81 patient clusters and form superclusters. The relative distances between the individual clusters are shown in Figure 3D-E. We divided the 81 clusters into 4 superclusters, which are represented in Figure 3B by the color of the squares. Supercluster 1 was formed with 24 neurons, supercluster 2 had 
medRxiv preprint doi: https://doi.org/10.1101/2020.06.24.20138859; this version posted June 24 , 2020. The copyright holder for this preprint (which was not certified by peer review) is the author/funder, who has granted medRxiv a license to display the preprint in perpetuity. patients within this cluster may be especially similar. superclusters. 24 variables were significantly different between the superclusters $(p<0.05)$ (Table S3).

182 We discovered that the clinical variables exhibit 3 main types of correlations with the superclusters:

183 continuous increase in value from cluster 1 to cluster 4 (Figure 3G), clusters 1 and 3 exhibiting the

184 same distribution and clusters 2 and 4 exhibiting another distribution (Figure $3 \mathrm{H}$ ), and 3 clusters

185 exhibiting the same median (Figure 3I). From these analyses, we could infer that patients with low

186 levels of CRP and serum immune cells likely define cluster 1 . Cluster 1 patients are also

187 predominantly female. Cluster 2 contains patients with slightly higher levels of CRP and serum

188 immune cells than cluster 1 . Compared to cluster 1 patients, fewer cluster 2 patient report coughing and fever. Cluster 2 patients are predominantly male. Cluster 3 contains patients with few reported symptoms, including less coughing, shortness of breath, fever, and sore throat. Cluster 3 is overwhelmingly female. Cluster 4 most likely contains patients not belonging to the other 3 clusters as it has few distinguishing features and high levels of missing data. 
medRxiv preprint doi: https://doi.org/10.1101/2020.06.24.20138859; this version posted June 24, 2020. The copyright holder for this preprint (which was not certified by peer review) is the author/funder, who has granted medRxiv a license to display the preprint in perpetuity.

algorithm that has been shown to outperform other more traditional algorithms in its accuracy and efficiency[13]. It can also take both continuous and discrete inputs and handle sparse data, in addition to having highly optimizable hyper-parameters[14]. training and testing patient sets, with $80 \%$ and $20 \%$ of the patients, respectively. Categorical variables were encoded as dummy variables. We then tuned the model using the Bayesian optimization method for hyperparameter search. We found the best hyperparameters to be gamma $=0.0933$, learning rate $=0.4068$, max depth $=6.558$, and n_estimators $=107.242$.

\subsection{Evaluation of XGBoost classification outcomes}

210 From the ROC curve of prediction results, we obtained an AUC of 0.990 (Figure 4A). However, 211 because there is an imbalance of class in our input (i.e. we have significantly more influenza patients 212 than COVID-19 patients), the precision recall (PR) curve may be better able to present our model's

213 results. ROC curves could be significantly influenced by skewing the distribution of classes in 214 classification, while PR curves would not be impacted by this action. We observed a slightly lower 215 AUC of 0.977 in our PR curve and computed the F1 score to be 0.929 (Figure 4B), which suggest that 216 our model is still highly accurate even when class imbalances are taken into account. The prediction 217 result from XGBoost's predict function was used to plot a confusion matrix (Figure 4C). From the 218 confusion matrix, we calculated a sensitivity of $92.5 \%$ and a specificity of $97.9 \%$. We found the most 219 important features in our prediction model to be age, CT scan result, temperature, lymphocyte 220 levels, fever, and coughing, in order of decreasing importance (Figure 4D). We also provided a 221 6-level decision tree sample of our XGBoost model (Figure 4E), which is not a representation of our 222 full model. 


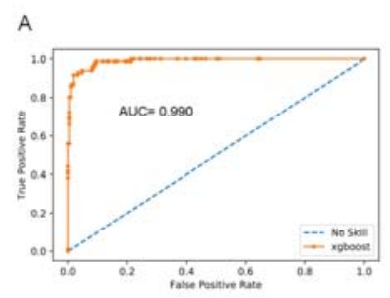

B

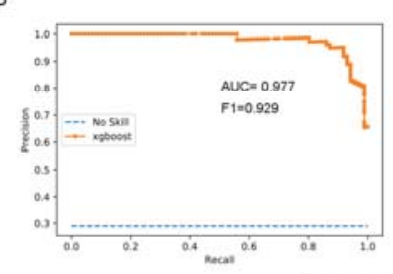

C

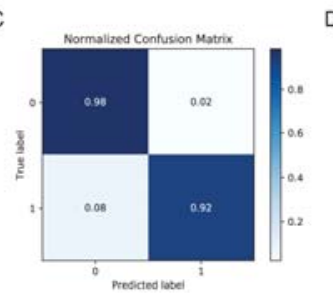

D

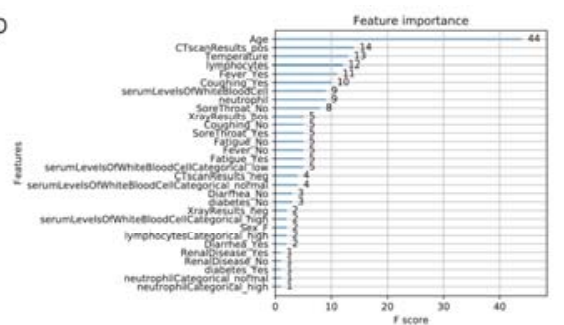

E
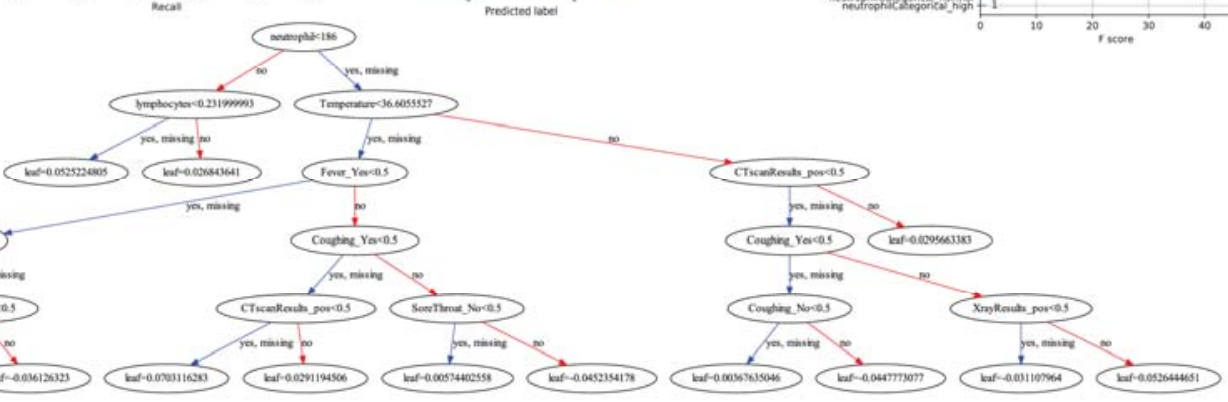

Figure 4. Summary of XGBoost classification of COVID-19 and influenza patients. A. ROC curve of prediction. B. Precision recall curve of prediction. C. Confusion matrix of prediction. D. Variables most important for classification, listed by decreasing order of importance. E. 6-level sample model of SOM decision tree construction.

\section{Discussion}

As the recent pandemic of COVID-19 unfolds across the world, the inability of countries to test

230 their citizens is heavily impacting their healthcare system's ability to fight the epidemic. Testing is

231 necessary for the identification and quarantine of COVID-19 patients. However, the multi-step

232 process required for the conventional SARS-Cov-2 test, via quantitative polymerase chain reaction

233 (qPCR), is creating difficulties for countries to test large numbers of suspected patients[15]. Testing

234 begins with a healthcare worker taking a swab from the patient. The swab is sent to a laboratory, and

235 viral RNA is extracted from the sample and reverse transcribed into DNA. The DNA is tagged with

236 a fluorescent dye and then amplified using a qPCR machine. If a high level of fluorescence is

237 observed compared to control, the sample is positive with SARS-Cov-2. Each step of the testing

238 process is susceptible to severe shortages[16].

In this study, we aim to mine published clinical data of COVID-19 patients to generate a new 
medRxiv preprint doi: https://doi.org/10.1101/2020.06.24.20138859; this version posted June 24,2020 . The copyright holder for this preprint

241 could be exploited for diagnosis with the aid of machine learning. Not only may underlying

242 relationships between clinical variables in COVID-19 be useful for the development of a

243 computational diagnostic test based on signs, symptoms, and laboratory results, these correlations

244 can also yield critical insights into the biological mechanisms of COVID-19 transmission and

245 infection.

246 Using correlational tests, we corroborated previous findings and expected results for 247 COVID-19 patients but also uncovered novel relationships between clinical variables. We found that 248 age is correlated with CRP level, an indicator of inflammation, and decreased platelet levels. It is 249 known that as age increases, the proinflammatory response becomes stronger, leading to increasing 250 CRP and decreasing platelet levels[17]. However, we found surprising correlations with gender, 251 including higher serum neutrophil and leukocyte levels in males compared to females. According to 252 the National Health and Nutrition Examination Survey, with data from over 5,600 individual, few 253 differences exist between male and females in the serum levels of these cells[18]. Another study with 254200 samples found that neutrophils are generally higher in women[19]. Correlations with gender 255 observed here may offer a piece of the explanation for why men infected with COVID-19 seem to 256 experience poorer prognosis, one of the important outstanding questions of COVID-19[20].

257 We also classified COVID-19 patients into different clusters using the SOM machine learning 258 algorithm. Two of the clusters are defined by low vs. high levels of immunological parameters, 259 including immune cell counts and CRP levels. A third cluster is defined by a tendency for less 260 reported symptoms, including sore throat, fever, and shortness of breath, and is predominantly 261 female.

262 Finally, using the machine learning algorithm XGBoost, we constructed a computational model 263 that successfully classified influenza patients from COVID-19 patients with high sensitivity and 264 specificity. We believe that our model demonstrated the feasibility of using data mining and 265 machine learning to inform diagnostic decisions for COVID-19. Such a model could be extremely 
medRxiv preprint doi: https://doi.org/10.1101/2020.06.24.20138859; this version posted June 24, 2020. The copyright holder for this preprint (which was not certified by peer review) is the author/funder, who has granted medRxiv a license to display the preprint in perpetuity.

266

267

268

269

270

271

272

273

274

275

276

277

278

280

281

282

283

284

285

286

287

288

289

290

useful for more effective identification of COVID-19 cases and hotspots, which could allow health officials to act before testing shortages could be addressed.

Despite promising results, several limitations exist for our study, all of which stem from the lack of large-scale clinical data. First, our sample size is severely limited because most clinical reports published do not publish individual-level patient data. Second, data on influenza signs and symptoms are equally inaccessible. We were only able to locate data for patients with H1N1 influenza A, which is not one of the active strains in the current influenza season. Third, many of our data sources are case studies that focused on specific cohorts of COVID-19 patients. This increases the chance of us capturing a patient population that is not representative of the general population, although this is an inherent risk of sampling. We anticipate that as more data are made openly available in the weeks and months to come, we will be able to build a more robust computational model. Therefore, we intend to provide the model we constructed as a computational framework for computation-aided diagnosis of COVID-19 data rather than a ready-to-use model. We also encourage researchers around the world to release de-identified patient data to aid in data mining and machine learning efforts against COVID-19.

\section{Materials and Methods}

\section{4,1 Literature search and inclusion criteria for studies}

Patient clinical data were manually curated from a PubMed search with the keyword “COVID-19." A total of 1,439 publications, dating from January 17, 2020 to March 23, 2020, were reviewed. All publications with no primary clinical data, including reviews, meta-analyses, and editorials, were excluded from our analysis. After manual review, we found 151 studies with individual-level data, encompassing data from 413 patients. All individual patient data with 2 more clinical variables reported per patient were included. Clinical variables sought for included demographics, signs and symptoms, laboratory test results, imaging results, and COVID-19 
medRxiv preprint doi: https://doi.org/10.1101/2020.06.24.20138859; this version posted June 24, 2020. The copyright holder for this preprint (which was not certified by peer review) is the author/funder, who has granted medRxiv a license to display the preprint in perpetuity.

diagnosis. No formal review protocol was used. No bias was assessed within or across studies

292 because we did not include any clinical trials or case-control studies.

293 For our machine learning classification task to discriminate COVID-19 patients from influenza

294 patients, we used clinical variables for 21 influenza patients from a study by Cheng et. al. and 1050

295 patients from the Influenza Research Database[11, 12]. Only H1N1 Influenza A virus cases were

296 included because of difficulties locating data from other strains.

\subsection{Correlational tests between pairs of clinical variables}

We sought to uncover correlations that could yield critical insights into the clinical characteristics of COVID-19 by correlating every variable to each other. For two continuous variables, the Spearman correlation test was applied. For one continuous variable and one categorical variable, the Kruskal-Wallis test was applied. For two different categorical variables, the chi-squared test will be applied. All statistical tests were considered significant if the $p$-value is 0.05

\section{4 or below.}

305 variable to ensure that they are equally weighted. 
medRxiv preprint doi: https://doi.org/10.1101/2020.06.24.20138859; this version posted June 24, 2020. The copyright holder for this preprint

(which was not certified by peer review) is the author/funder, who has granted medRxiv a license to display the preprint in perpetuity.

All rights reserved. No reuse allowed without permission.

16 of 21

317 based on minimal topographic error. We then aggregated the neurons into super-clusters using the 318 superClass method in SOMbrero.

319

320

4.4 Preprocessing of data for machine learning classification

Data were preprocessed by combining data from COVID-19 cases and influenza cases into a

322 single matrix, followed by removal of any clinical variables that were not present in both the

COVID-19 dataset and the influenza dataset. 19 clinical variables were included as machine learning

324 input. The variables include age, sex, serum levels of neutrophil (continuous and ordinal), serum

325 levels of leukocytes (continuous and ordinal), serum levels of lymphocytes (continuous and ordinal),

326 result of CT scans, result of chest X-rays, reported symptoms (diarrhea, fever, coughing, sore throat,

327 nausea, and fatigue), body temperature, and underlying risk factors (renal diseases and diabetes).

328 Categorical data were converted to dummy variables using the get dummies function in Pandas

329 because non-numerical data are not allowed in our machine learning algorithm.

4.5 Performing XGBoost classification

The eXtreme Gradient Boosting algorithm (XGBoost), an ensemble machine learning method

widely known for its superior performance over other machine learning methods, was selected for

our study[13]. We first split our data into $80 \%$ training dataset and $20 \%$ testing dataset. 5 -fold

cross-validation was then performed, with 70 boosting rounds (iterations), and fed into a Bayesian

optimization function for calculation of the best hyperparameters for XGBoost. The

336 hyperparameters tuned included max depth, gamma, learning rate, and n estimators. Bayesian

337 optimization was performed with an initial 8 steps of random exploration followed by 5 iterations.

338 The expected improvement acquisition function was used.

339

4.6 Evaluation of XGBoost results

341 XGBoost results were evaluated by plotting a receiver operating characteristic (ROC) curve and 342 a precision recall (PR) curve. The area under the curve (AUC) was also calculated for both curves. 
medRxiv preprint doi: https://doi.org/10.1101/2020.06.24.20138859; this version posted June 24, 2020. The copyright holder for this preprint

(which was not certified by peer review) is the author/funder, who has granted medRxiv a license to display the preprint in perpetuity.

All rights reserved. No reuse allowed without permission.

17 of 21

\section{Declarations}

344 Ethics approval and consent to participate: Not applicable.

345 Consent for publication: Not applicable.

346 Availability of data and materials: The datasets during and/or analysed during the current study

347 available from the corresponding author on reasonable request.

348 Competing Interests: The authors declare that they have no competing interests.

349 Funding: University of California, Office of the President/Tobacco-Related Disease Research

350 Program Emergency COVID-19 Research Seed Funding Grant (R00RG2369) to W.M.O.

351 Author Contributions: Conceptualization, W.M.O.; methodology, W.M.O. and W.T.L.; software,

352 W.T.L. J.M., and N.S.; validation, W.T.L., J.M., and N.S.; formal analysis, W.T.L., J.M., and N.S.;

353 investigation, W.T.L, J.M., N.S., G.C., J.C., J.C.T., L.A., C.O.H., J.X., L.M.W., T.Z., A.L., A.G., and

354 T.K.H.; resources, W.M.O.; data curation, W.T.L, J.M., N.S., G.C., J.C., J.C.T., L.A., C.O.H., J.X.,

355 L.M.W., T.Z., A.L., A.G., and T.K.H.; writing-original draft preparation, W.T.L. and N.S.;

356 writing - review and editing, W.M.O., E.Y.C., M.R.R., S.Z.K., and M.A.Y.; visualization, W.T.L., J.M.,

357 and N.S.; supervision, W.M.O.; project administration, W.M.O.; funding acquisition, E.Y.C. All

358 authors have read and agreed to the published version of the manuscript.

359 Acknowledgments: Not applicable.

360 Abbreviations

$\begin{array}{ll}\text { CRP } & \text { C-reactive Protein } \\ \text { ANOVA } & \text { Analysis of Vatriance } \\ \text { SOM } & \text { Self-organizing map } \\ \text { XGBoost } & \text { Extreme Gradient Boosting } \\ \text { ROC } & \text { Receiver Operating Characteristic } \\ \text { AUC } & \text { Area Under the Curve } \\ \text { PR } & \text { Precision-Recall }\end{array}$


medRxiv preprint doi: https://doi.org/10.1101/2020.06.24.20138859; this version posted June 24, 2020. The copyright holder for this preprint

(which was not certified by peer review) is the author/funder, who has granted medRxiv a license to display the preprint in perpetuity.

All rights reserved. No reuse allowed without permission.

18 of 21

361

3621.

363

364

365

366

367

368

369

370

371

372

373

374

375

376

377

378

379

380

381

382

383

384

385

386

387

388

389

390

391

392

393

394

395

396

397

398

39916.

40017.

40118.

402

\section{References}

1. Chang, Mo G, Yuan X, Tao Y, Peng X, Wang F, Xie L, Sharma L, Dela Cruz CS, Qin E: Time Kinetics of Viral Clearance and Resolution of Symptoms in Novel Coronavirus Infection. Am J Respir Crit Care Med 2020.

2. Zhang MQ, Wang XH, Chen YL, Zhao KL, Cai YQ, An CL, Lin MG, Mu XD: [Clinical features of 2019 novel coronavirus pneumonia in the early stage from a fever clinic in Beijing]. Zhonghua Jie He He Hu Xi Za Zhi 2020, 43(3):215-218.

3. Feng K, Yun YX, Wang XF, Yang GD, Zheng YJ, Lin CM, Wang LF: [Analysis of CT features of 15 Children with 2019 novel coronavirus infection]. Zhonghua Er Ke Za Zhi 2020, 58(0):E007.

4. Li Y, Guo F, Cao Y, Li L, Guo Y: Insight into COVID-2019 for pediatricians. Pediatr Pulmonol 2020.

5. HUANG P: If Most Of Your Coronavirus Tests Come Back Positive, You're Not Testing Enough. In: NPR. 2020.

6. Sun P, Qie S, Liu Z, Ren J, Li K, Xi J: Clinical characteristics of hospitalized patients with SARS-CoV-2 infection: A single arm meta-analysis. J Med Virol 2020.

7. Yang J, Zheng Y, Gou X, Pu K, Chen Z, Guo Q, Ji R, Wang H, Wang Y, Zhou Y: Prevalence of comorbidities in the novel Wuhan coronavirus (COVID-19) infection: a systematic review and meta-analysis. Int J Infect Dis 2020.

8. Cao Y, Liu X, Xiong L, Cai K: Imaging and Clinical Features of Patients With 2019 Novel Coronavirus SARS-CoV-2: A systematic review and meta-analysis. J Med Virol 2020.

9. Kolifarhood G, Aghaali M, Mozafar Saadati H, Taherpour N, Rahimi S, Izadi N, Hashemi Nazari SS: Epidemiological and Clinical Aspects of COVID-19; a Narrative Review. Arch Acad Emerg Med 2020, 8(1):e41.

10. Jerez JM, Molina I, Garcia-Laencina PJ, Alba E, Ribelles N, Martin M, Franco L: Missing data imputation using statistical and machine learning methods in a real breast cancer problem. Artif Intell Med 2010, 50(2):105-115.

11. Cheng Y, Zhao H, Song P, Zhang Z, Chen J, Zhou YH: Dynamic changes of lymphocyte counts in adult patients with severe pandemic H1N1 influenza A. J Infect Public Health 2019, 12(6):878-883.

12. Squires RB, Noronha J, Hunt V, Garcia-Sastre A, Macken C, Baumgarth N, Suarez D, Pickett BE, Zhang $\mathrm{Y}$, Larsen $\mathrm{CN}$ et al: Influenza research database: an integrated bioinformatics resource for influenza research and surveillance. Influenza Other Respir Viruses 2012, 6(6):404-416.

13. Chen T, Carlos G: XGBoost: A Scalable Tree Boosting System. KDD '16: Proceedings of the 22nd ACM SIGKDD International Conference on Knowledge Discovery and Data Mining 2016:9.

14. Al'Aref SJ, Maliakal G, Singh G, van Rosendael AR, Ma X, Xu Z, Alawamlh OAH, Lee B, Pandey M, Achenbach $S$ et al: Machine learning of clinical variables and coronary artery calcium scoring for the prediction of obstructive coronary artery disease on coronary computed tomography angiography: analysis from the CONFIRM registry. Eur Heart J 2020, 41(3):359-367.

15. Hollingsworth J: A coronavirus test can be developed in 24 hours. So why are some countries still struggling to diagnose? In: CNN. 2020.

Yong E: How the Pandemic Will End. In: The Atlantic. 2020.

Molloy EJ, Bearer CF: COVID-19 in children and altered inflammatory responses. Pediatr Res 2020.

18. Andersen CJ, Vance TM: Gender Dictates the Relationship between Serum Lipids and Leukocyte Counts in the National Health and Nutrition Examination Survey 1999(-)2004. J Clin Med 2019, 8(3). 
medRxiv preprint doi: https://doi.org/10.1101/2020.06.24.20138859; this version posted June 24, 2020. The copyright holder for this preprint (which was not certified by peer review) is the author/funder, who has granted medRxiv a license to display the preprint in perpetuity.

403 19. Bain BJ, England JM: Normal haematological values: sex difference in neutrophil count. Br Med J

404 1975, 1(5953):306-309.

405 20. Wenham C, Smith J, Morgan R, Gender, Group C-W: COVID-19: the gendered impacts of the

406

407 outbreak. Lancet 2020, 395(10227):846-848.

21. Boelaert J, Bendhaiba L, Olteanu M, Villa-Vialaneix N: SOMbrero: an R Package for Numeric and 408 Non-numeric Self-Organizing Map. 2013.

409

Table 1: Clinical Variables Summary of Meta-analysis

\begin{tabular}{|c|c|c|c|c|}
\hline \multicolumn{5}{|c|}{ Continuous Variable } \\
\hline Clinical Variable & $\begin{array}{ll}\# & \text { of } \\
\text { Data } & \\
\end{array}$ & mean & median & variance \\
\hline Age & 389 & 38.91306 & 39 & 21.85783 \\
\hline NumberOfFamilyMembersInfected & 54 & 3.37037 & 2 & 2.6338 \\
\hline neutrophil & 103 & 6.854078 & 3.31 & 12.62838 \\
\hline SerumLevelsOfWhiteBloodCell & 130 & 7.031223 & 5.965 & 4.250785 \\
\hline lymphocytes & 135 & 2.022841 & 0.98 & 4.207139 \\
\hline Plateletes & 50 & 220.32 & 185.5 & 146.3334 \\
\hline CReactiveProteinLevels & 139 & 31.18187 & 15 & 40.4953 \\
\hline Eosinophils & 8 & 0.06125 & 0.01 & 0.070078 \\
\hline RedBloodCells & 4 & 4.225 & 4.205 & 0.189011 \\
\hline Hemoglobin & 24 & 45.5 & 14.5 & 49.99953 \\
\hline Procalcitonin & 33 & 2.586394 & 0.07 & 12.54482 \\
\hline DurationOfIllness & 88 & 14.06818 & 12 & 8.970653 \\
\hline DaysToDeath & 3 & 12.66667 & 12 & 6.548961 \\
\hline DaysBeforeSymptomsAppear & 38 & 7.368421 & 6 & 5.142297 \\
\hline NumberOfAffectedLobes & 24 & 1.75 & 2 & 1.163687 \\
\hline TimeBetweenAdmissionAndDiagnosis & 47 & 5.893617 & 6 & 4.116568 \\
\hline bodyTemperature & 67 & 37.6209 & 37.5 & 0.972999 \\
\hline Hematocrit & 7 & 0.320286 & 0.355 & 0.078175 \\
\hline ActivatedPartialThromboplastinTime & 9 & 33.18889 & 33.4 & 3.642784 \\
\hline fibrinogen & 9 & 3.685556 & 3.91 & 0.752184 \\
\hline urea & 19 & 3.123158 & 3 & 0.863884 \\
\hline \multicolumn{5}{|c|}{ Discrete Variable } \\
\hline Variables & & Number & & Percentage \\
\hline \multicolumn{5}{|l|}{ Sex } \\
\hline M & & 194 & & 49.4898 \\
\hline $\mathrm{F}$ & & 198 & & 50.5102 \\
\hline \multicolumn{5}{|l|}{ Community Transmission } \\
\hline Yes & & 93 & & 37.5 \\
\hline
\end{tabular}


medRxiv preprint doi: https://doi.org/10.1101/2020.06.24.20138859; this version posted June 24, 2020. The copyright holder for this preprint (which was not certified by peer review) is the author/funder, who has granted medRxiv a license to display the preprint in perpetuity. All rights reserved. No reuse allowed without permission.

20 of 21

\begin{tabular}{|c|c|c|}
\hline No & 46 & 18.54839 \\
\hline No/Wuhan & 109 & 43.95161 \\
\hline \multicolumn{3}{|l|}{ Neutrophil } \\
\hline low & 15 & 11.81102 \\
\hline normal & 83 & 65.35433 \\
\hline high & 29 & 22.83465 \\
\hline \multicolumn{3}{|c|}{ Serum Levels Of White Blood Cell } \\
\hline low & 55 & 32.35294 \\
\hline normal & 94 & 55.29412 \\
\hline high & 21 & 12.35294 \\
\hline \multicolumn{3}{|c|}{ Lymphocytes } \\
\hline low & 86 & 48.86364 \\
\hline normal & 73 & 41.47727 \\
\hline high & 17 & 9.659091 \\
\hline \multicolumn{3}{|c|}{ C Reactive Protein(CRP) Levels } \\
\hline normal & 60 & 37.97468 \\
\hline high & 98 & 62.02532 \\
\hline \multicolumn{3}{|c|}{ CT Scan Results } \\
\hline pos & 124 & 89.20863 \\
\hline neg & 15 & 10.79137 \\
\hline \multicolumn{3}{|c|}{ RT-PCR Results } \\
\hline pos & 100 & 96.15385 \\
\hline neg & 4 & 3.846154 \\
\hline \multicolumn{3}{|c|}{ X-ray Result } \\
\hline pos & 35 & 74.46809 \\
\hline neg & 12 & 25.53191 \\
\hline \multicolumn{3}{|l|}{ GGO } \\
\hline Yes & 92 & 96.84211 \\
\hline No & 3 & 3.157895 \\
\hline \multicolumn{3}{|l|}{ Diarrhea } \\
\hline Yes & 30 & 45.45455 \\
\hline No & 36 & 54.54545 \\
\hline \multicolumn{3}{|l|}{ Fever } \\
\hline Yes & 261 & 91.25874 \\
\hline
\end{tabular}


medRxiv preprint doi: https://doi.org/10.1101/2020.06.24.20138859; this version posted June 24, 2020. The copyright holder for this preprint (which was not certified by peer review) is the author/funder, who has granted medRxiv a license to display the preprint in perpetuity. All rights reserved. No reuse allowed without permission.

21 of 21

\begin{tabular}{|c|c|c|}
\hline No & 25 & 8.741259 \\
\hline \multicolumn{3}{|c|}{ Coughing } \\
\hline Yes & 164 & 82.82828 \\
\hline No & 34 & 17.17172 \\
\hline \multicolumn{3}{|c|}{ Shortness Of Breath } \\
\hline Yes & 45 & 60 \\
\hline No & 30 & 40 \\
\hline \multicolumn{3}{|c|}{ Sore Throat } \\
\hline Yes & 37 & 60.65574 \\
\hline No & 24 & 39.34426 \\
\hline \multicolumn{3}{|c|}{ Nausea/Vomiting } \\
\hline Yes & 18 & 52.94118 \\
\hline No & 16 & 47.05882 \\
\hline \multicolumn{3}{|c|}{ Pregnant } \\
\hline Yes & 43 & 66.15385 \\
\hline No & 22 & 33.84615 \\
\hline \multicolumn{3}{|c|}{ Fatigue } \\
\hline Yes & 8 & 61.53846 \\
\hline No & 5 & 38.46154 \\
\hline
\end{tabular}



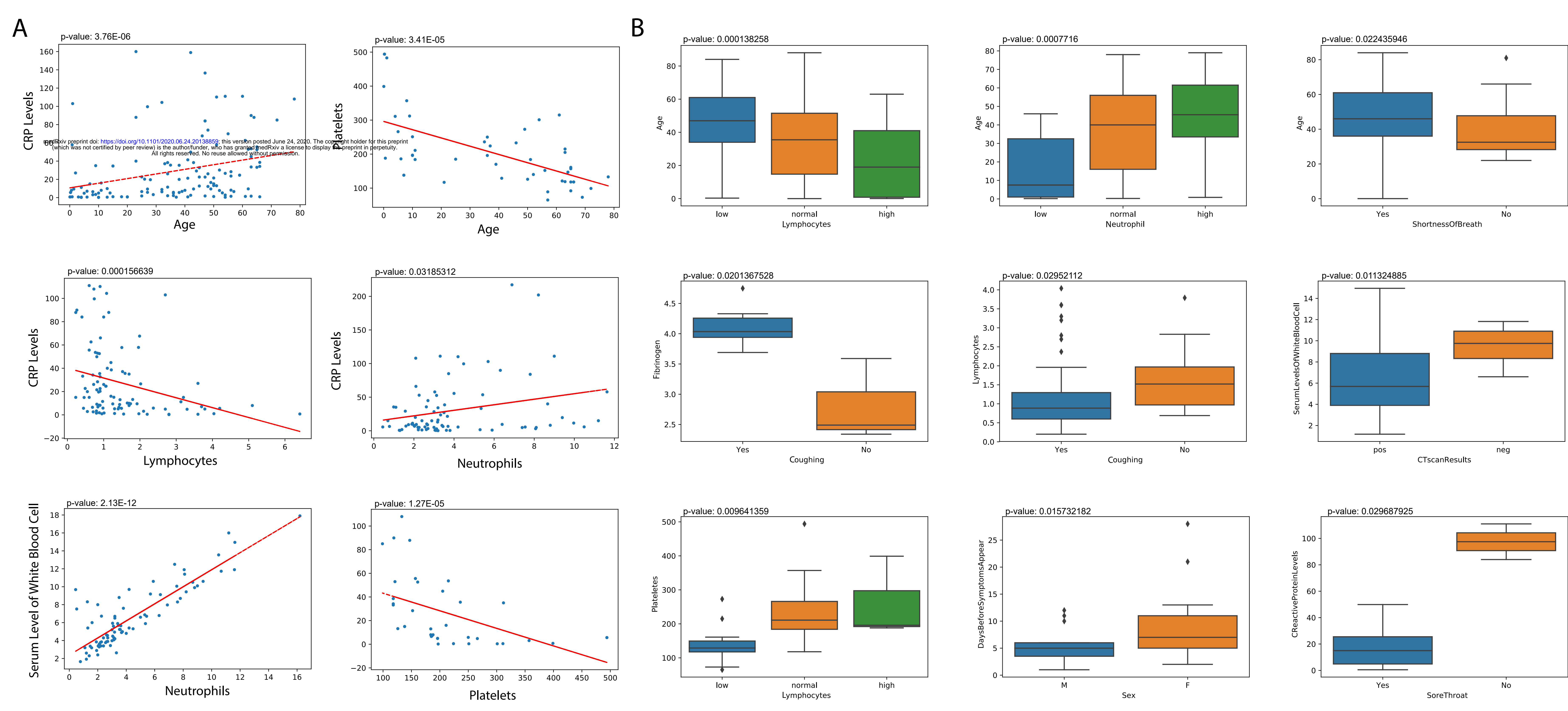
A Contingency Table: Lymphocyte Levels vs Gender

\begin{tabular}{|c|c|c|c|c|}
\hline \multicolumn{4}{|c|}{ Contingency Table: Lymphocyte Levels vs Gender } & \multirow{2}{*}{$\begin{array}{l}\text { p-value: } 0.02015 \\
\text { All }\end{array}$} \\
\hline & & Male & Female & \\
\hline & Low & 39 & 47 & 86 \\
\hline & Normal & 33 & 39 & 72 \\
\hline & High & 14 & 3 & 17 \\
\hline & All & 86 & 89 & 175 \\
\hline
\end{tabular}

B

Contingency Table: Neutrophil Levels vs Gender
\begin{tabular}{|l|l|l|l|}
\hline & Male & Female & All \\
\hline Low & 10 & 5 & 15 \\
\hline$\overline{\bar{\tau}}$ & 35 & 48 & 83 \\
\hline Normal & 20 & 9 & 29 \\
\hline High & 65 & 62 & 127 \\
\hline \multirow{2}{*}{ All } & & & 0.01566 \\
\hline
\end{tabular}

C

Contingency Table: Serum Leukocyte Levels vs. Gender p-value: 0.002905

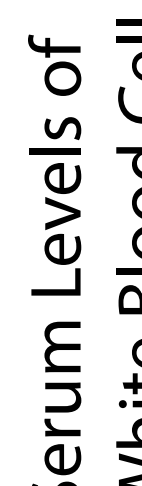

$\overline{0}$

Low

Normal

$\stackrel{ \pm}{ \pm}$ High

All

\begin{tabular}{|l|}
\hline Male \\
\hline 16 \\
\hline 12 \\
\hline 78
\end{tabular}

\begin{tabular}{|l|l|}
\hline Female & All \\
\hline 39 & 55 \\
\hline 40 & 90 \\
\hline 7 & 19 \\
\hline 86 & 164 \\
\hline
\end{tabular}
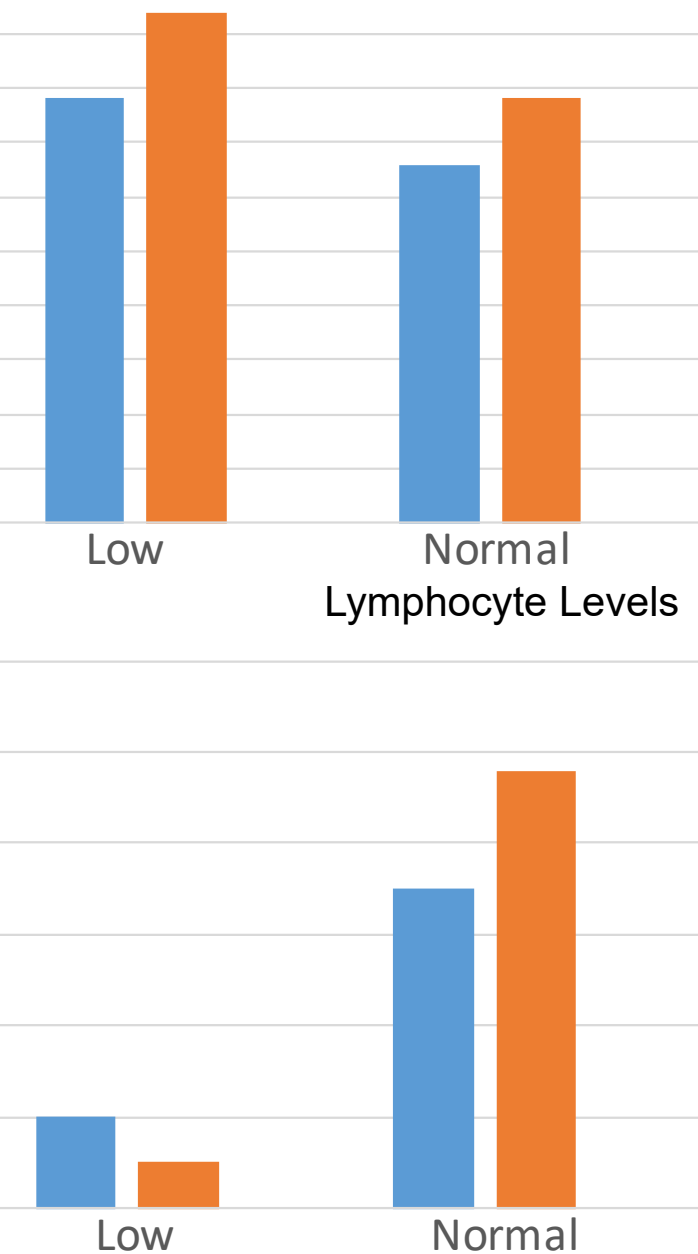
Neutrophil Levels

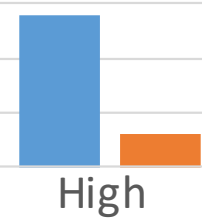

High

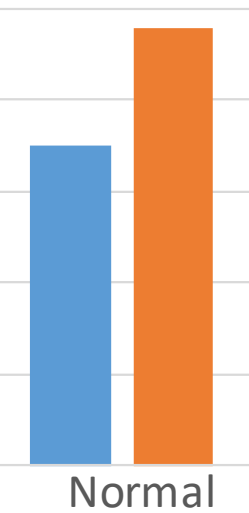

Male

-Female

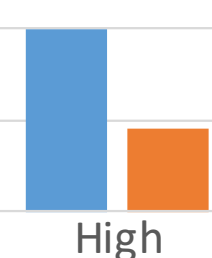

High

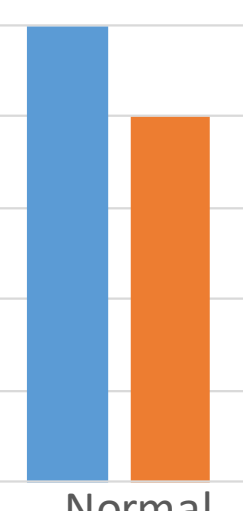

- Male

- Female 
$A$

Topographic Error vs Grid Size

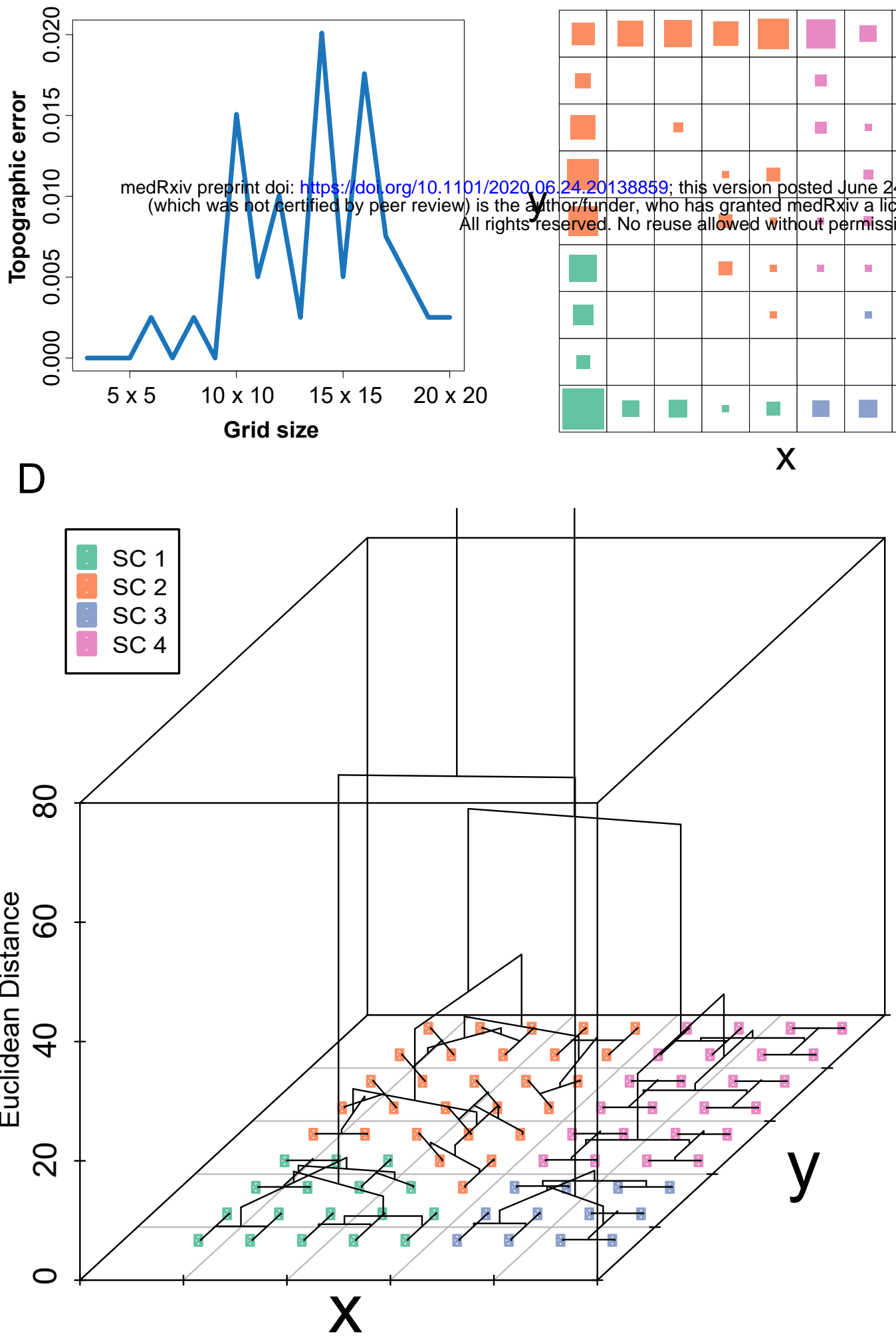

G

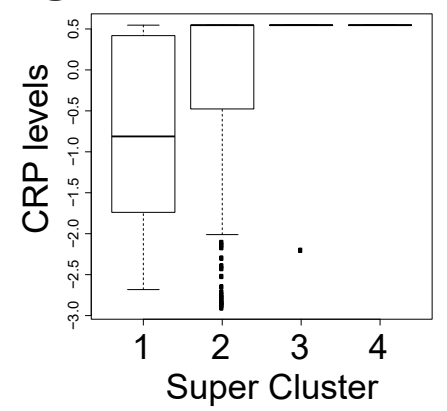

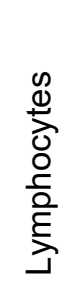

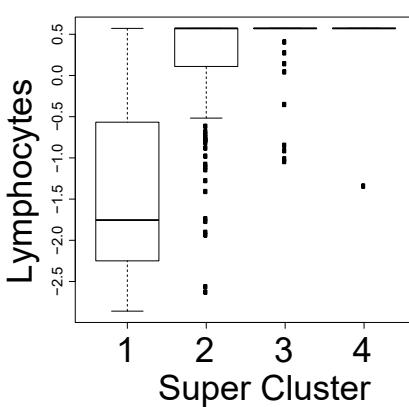

Super Cluster
2D Grid of SOM Neurons

C

Patient Number Vs. Neuron

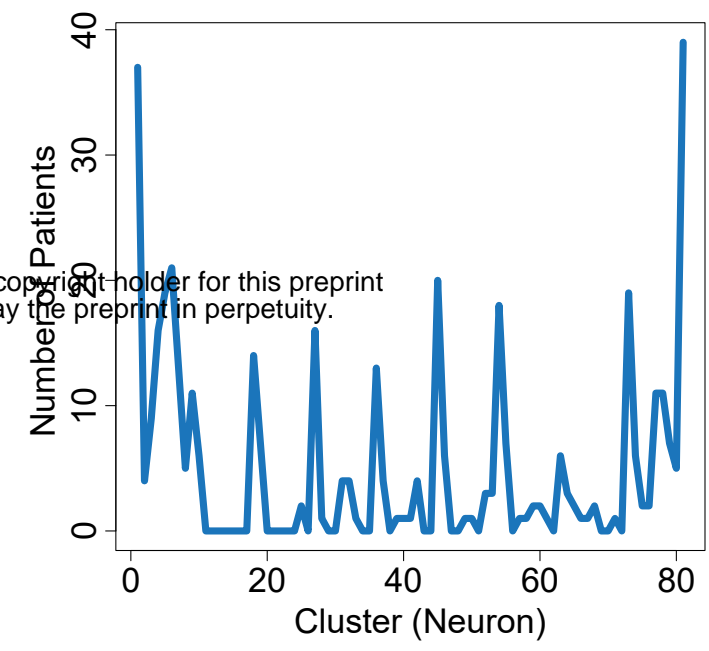

Superclusters dendrogram
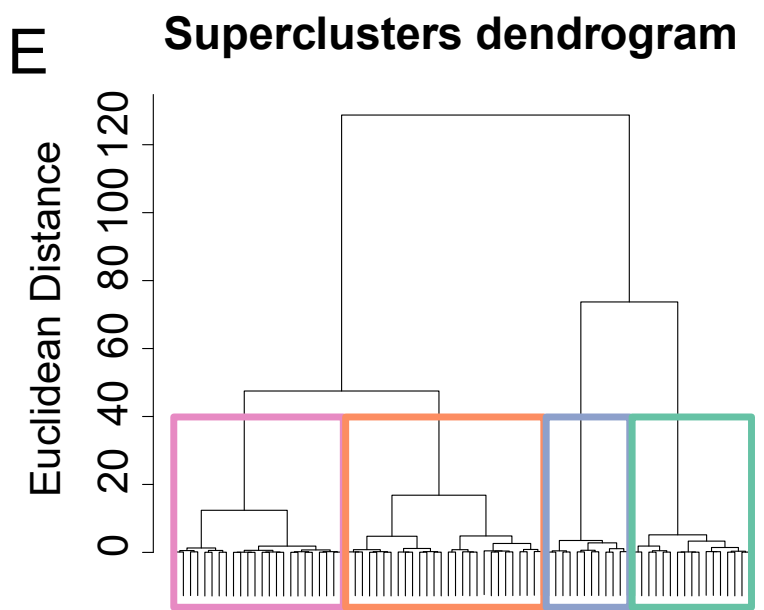

Neurons

F Gradient Map of Distances between Neurons

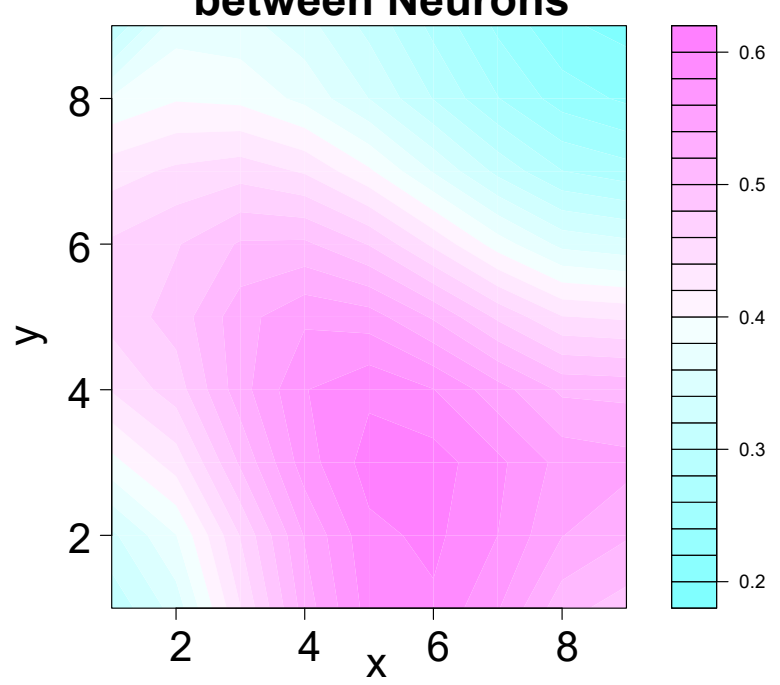

I
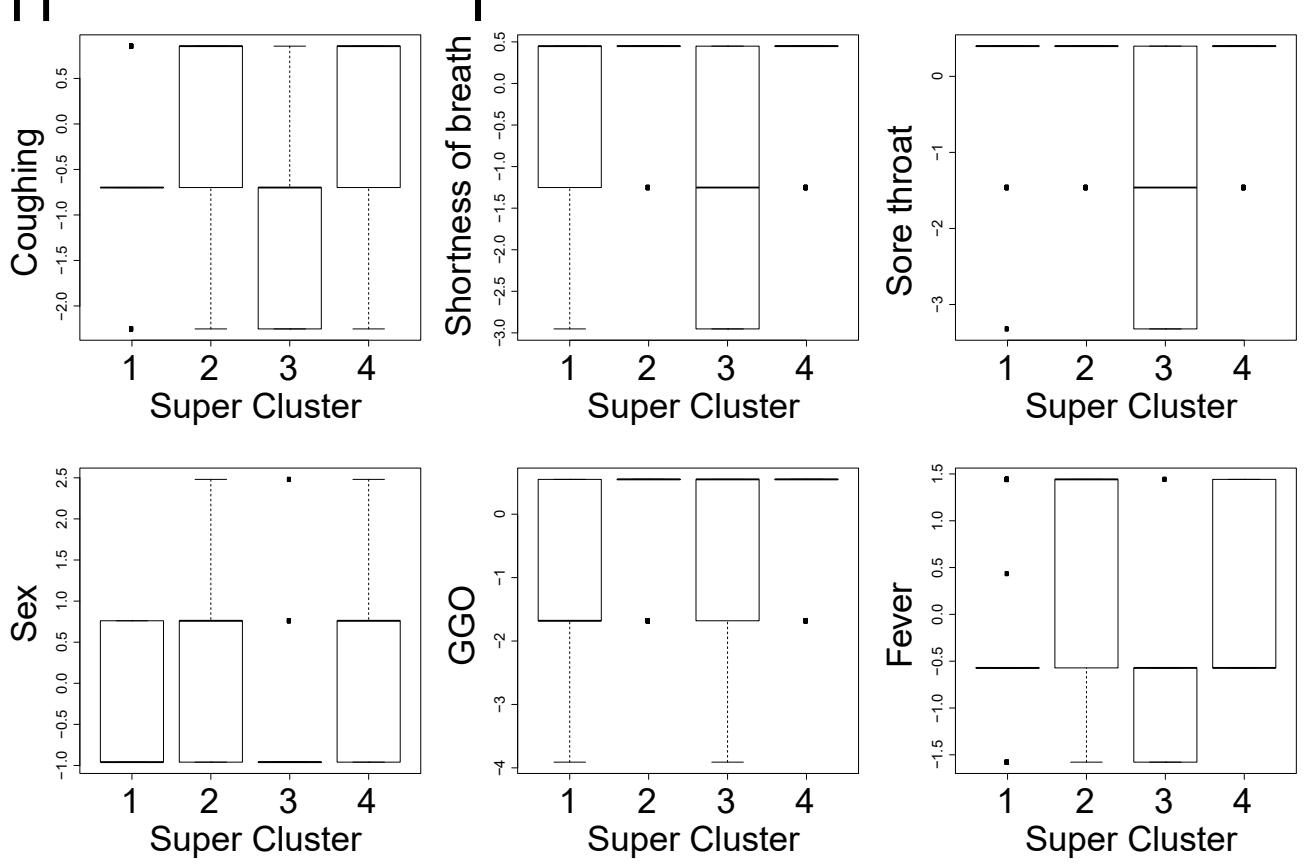
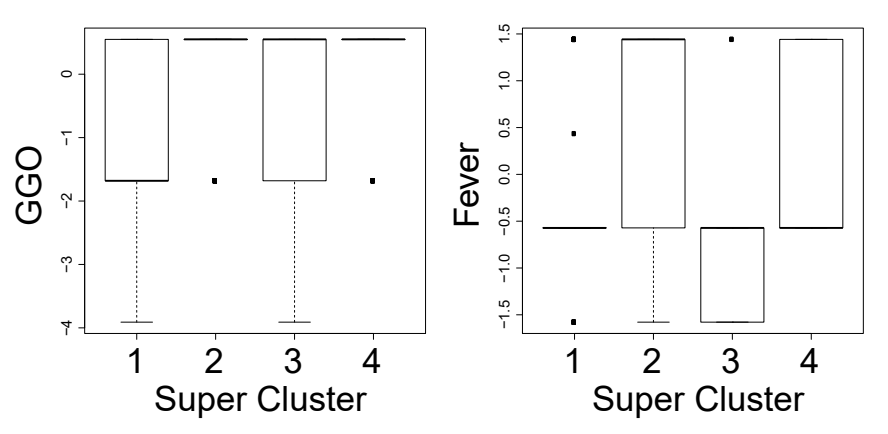
